\title{
UN ESTUDIO SOBRE EL GÉNERO EN LA TRAGEDIA GRIEGA (LOGOS, POLIS Y GENOS)
}

\author{
César García Alvarez \\ Universidad San Sebastián. Chile
}

Resumen: El autor inicia su trabajo, planteando las diversas interrogantes que la cultura griega nos sugiere sobre la mujer; se centra posteriormente, y en forma muy detallada, en la visión que de la mujer nos entrega la tragedia griega; para ello, divide su estudio, teniendo en cuenta tres ideas fundamentales: Logos, Polis y Genos. Concluye, finalmente: Es necesario matizar el tan traído como llevado tópico: "La mujer en Grecia, una silente sometida al más duro patriarcado".

Palabras claves: Mujer - tragedia - logos - polis - genos - Grecia

\section{A STUDY ON GENDER IN GREEK TRAGEDY (LOGOS, POLIS AND GENOS)}

\begin{abstract}
The author begins his work setting the diverse questions wich Greek culture suggests about woman. After that, it focuses in all detail in the view of woman present in Greek tragedy; to do that, he divides his work keeping in mind three fundamental ideas: Logos, Polis and Genos. He concludes that it necessary to.
\end{abstract}

Key words: Woman - tragedy - logos - polis - genos - Greece

Recibido: 18.11.13 - Aceptado: 22.01.2014

Correspondencia: CÉSAR GARCÍA ÁlVAREZ - bizantinoscesar@gmail.com Doctor en Filosofía con mención en Literatura Tel- (56-2) 22693878- 22392292. 
$\mathbf{I}$

\section{ntroducción}

La mujer en la literatura griega antigua, es la mujer que no habla. Los clásicos griegos callan en unos casos y acallan a la mujer en otros. Pericles en el discurso fúnebre en honor a los soldados muertos contra Esparta, apenas quiere referirse a las viudas allí presentes, pero siente la obligación de hacerlo cuando seńala: "Si debo referirme a las mujeres viudas, que en el futuro los hombres no hablen mal de vosotras" (Tuc. 2,45,2). San Pablo hereda este discurso cultural griego, cuando a la mujer se refiere en la Carta a los Corintios (14: 33-39): "In ecclesia, mulieres tacent", "las mujeres en la iglesia, callan".

No obstante lo anterior, es necesario precisar los alcances de este silencio de la mujer en Grecia. Los estudios generalistas sobre el tema, tan abundantes, incluimos las valiosas y documentadas obras de Sarah Pomeroy y Marina Picazo, son siempre de temer; en realidad, saber de todo es saber de nada. Los estudios generalistas, sin la base filológica, apenas tienen valor; hace ya muchos años que Umberto Eco nos enseñó que "todo lo que se dice tiene el valor de los argumentos con que se dice". Desdeñar, en consecuencia, los comentarios de texto, es desdeñar los cimientos de cualquier investigación interpretativa. La visión generalista - con que se ha construido una imagen menoscabada de la mujer griega- es como la del periodista experto en cultura general, su noticia se puede creer, pero no es creíble. Lo decía Claudio Arrau cuando le preguntaron por qué en sus interpretaciones musicales al piano, se centraba casi exclusivas en la obra de Beethoven, y contestó: "Interpreto también otros autores, pero en Beethoven soy creíble, en las demás interpretaciones, puedo ser creíble”. Las concepciones generalistas se diferencian de las filológicas, como la estrategia de la táctica en el campo militar. Se ha dicho: No fue Jerjes, sentado en un trono en el alto del monte Aigaleo, con su visión generalista de estrategia quien perdió la batalla de 
Salamina, fueron los comandantes de sus navíos, que no resolvieron las situaciones puntuales, tácticamente presentadas por los griegos en los entreverados golfos de la isla Salamina. El presente estudio intenta huir de estas orientaciones generales y quiere estar pegado al sentido filológico.

¿Pero sobre el tema de la mujer en Grecia, se podrá añadir algo más a la extensa bibliografía ya existente, sobre todo, después de la segunda oleada de feminismo desatada a partir del ańo 1970? Una mirada a la bibliografía existente, desalienta cualquier ulterior investigación, si no fuese porque sobre el tema existen todavía más preguntas que respuestas. Ofrecemos aquí un pequeño repertorio de preguntas, útiles para futuros investigadores sobre el género en Grecia.

¿Era la mujer una postergada en el mundo griego o tenía funciones distintas, como su destacada contribución a la economía desde la industria textil? ¿La imagen de los griegos sobre la mujer es la misma que la creada por los alemanes a partir del siglo XVIII? ¿Se puede hablar de la mujer en el mundo griego cuando las diosas, las reinas, las profetisas y los entes colectivos como "las bacantes" y "las oceánidas" tienen tratamiento distinto? Recuérdese el himno a Artemisa (Hipólito, vv.62-72), a ella se le proclama: "Augusta", "augusta muy reverenciada”," "bella", "la más bella de las vírgenes", "copiosa de oro" ¿El tratamiento a la mujer era el mismo en todas las polis? Atenas no era Esparta (H.García; N. Loraux). ¿Cómo consensuar mujeres tan distintas y hasta opuestas como Antígona e Ismene, Medea y Yocasta, Clitemnestra que asesina a su esposo y Andrómaca que lo exalta? Postergación de la mujer griega, como tantas veces se dice hoy, es un término valorativo, supone una concepción teórica-cultural ¿es legítimo aplicar nuestra concepción sobre la mujer a otras culturas, a la griega o a la musulmana de hoy (Gomme, 1937; Wagner-Hasel, 1989)? ¿Cómo concordar la idea de un gineceo - supuesta prisión doméstica de las mujeres- con el peso que en la sociedad tenía el imaginario femenino en los vasos e iconografía en general? ¿Se puede liquidar el tema citando dos o tres textos clásicos a favor o en contra de la mujer? La asimetría de los géneros se ha dado en todas las culturas, cada una lo ha planteado míticamente de forma distinta, Hesíodo - Teogoníalo hizo para los griegos, pero la vida social, la necesidad de la convivencia y el amor a los hijos ¿no rompe toda asimetría teórica? El mito de Pandora - Los trabajos y los días - omite la función procreadora de la mujer en Grecia ¿no es sospechoso? La Mitología no siempre coincide con la Sociología, como la vida de las Constituciones de los pueblos no es siempre la vida misma de los pueblos. 
¿Al hablar de la mujer en Grecia, a veces supuestamente peyorativos, los autores antiguos separaban el concepto mítico de mujer, de el de la mujer del siglo $\mathrm{V}$ o involucraban ambos conceptos, como sucede con Medea pariente de Circe y a la vez inserta en la vida de Corinto (A.M.Iriarte)? Desde Cassirer y Ricoeur sabemos, sino antes, que el lenguaje tiene una función simbólica ¿qué quería decir Esquilo, Sófocles y sobre todo Eurípides en frases de menoscabo a la mujer (Richlin, 1991)? Hoy a las hijas les dan consejos que nos ahorramos para los hijos varones ¿̇las consideramos inferiores, con ello? Las advertencias, consejos y afirmaciones que los griegos hacían a las mujeres ¿no eran un "cuidate de la hybris, a la que eres más propensa, la sofrosyne es nuestro ideal”? ¿No incide en este supuesto antifeminismo griego la idea de un lenguaje claro (“varonil”) única forma de sustentar la democracia, frente al lenguaje enigmático de la mujer y también de los tan combatidos sofistas? ¿Qué papel jugaba la sexualidad y el "genos" en Grecia, y que llevaba a cuidar tan celosamente, a veces acremente, la fuente de la descendencia, a la mujer? ¿Qué decir del destacado tratamiento que el tema femenino tiene en la iconografía general griega (Louis Gernet; J-P Vernant)? La historia de la sexualidad, hasta Foucault, estaba sin hacer, y él murió sin concluir su obra. ¿Eran los griegos en el tratamiento de la mujer distintos de los hombres de todas las épocas, al ver a la mujer como una "desvitalizadora" del hombre que le da, como dicen los franceses una "petit mort", es devoradora del hombre? Advirtamos que en griego "gaster" significa útero y a la vez estómago devorador. ¿En Grecia la censura era a la mujer o al amor? Conviene revisar los versos 538 a 543 de Fedra, para dar una respuesta exacta al tema. ¿No confundiremos a veces los conceptos de ser y función, al atribuir a la mujer una condición, que no es tal, sino una función? Aristóteles lo señala: "El hombre y la mujer tienen la misma alma y capacidad deliberativa, solo que la mujer transitoriamente está desprovista de autoridad" (Politica, 1,13,78) ¿El género dramático, específicamente la tragedia de Eurípides y la comedia de Aristófanes, de donde proceden muchas conceptualizaciones sobre la mujer griega, ¿no es acaso un género "efectista" que buscaba provocar, desconcertar, contrastar, agredir, sorprender, interrogar, - tesis de Kitto- y no tanto ideológico y costumbrista? Finalmente, la imagen de la mujer en Grecia debe entenderse en un mundo de "sacralidad" o mítico, proyectarle nuestras ideas provenientes de una cultura de la "profanidad", es hacer una lectura no directa, sino filtrada. Conviene leer el estudio de Jean-Pierre Vernant sobre Hestía y Hermes, dioses 
desde los que hay que ver al hombre y a la mujer en Grecia. Estas y otras mil preguntas se pueden hacer al hablar sobre la mujer en el mundo griego.

La presente investigación trata de un estudio de la situación de la mujer en Grecia, desde el análisis de tan solo tres palabras, pero muy repetidas en las tragedias griegas: Logos, polis y genos.

\section{Logos}

Iniciamos este apartado con el texto de Antígona: "La irreflexión entre los hombres, es, con mucho, el mayor de los males humanos" (v.1243). Aquí se habla de aboylía, no rigurosamente sobre logos en cuanto razón; sin embargo, su significado puede entenderse como argumentación. Aristóteles en su Retórica señala que existen dos formas de logos, por persuasión y por argumentación. El logos razonado se encuentra en la filosofía, y corresponde a un ejercicio del hombre, su nombre es apofántico o lógico, mientras que el logos de la persuasión o pathos es el de la tragedia, espacio preferente de la mujer, llamado también logos semántico, un logos particularmente estudiado por Marta Nussbaum en Teoría del deseo (2003): "Evitar la emoción es evitar, en parte, la verdad", señala Nussbaum, comentando a Aristóteles. En ambos casos, para distinguir cada singularidad, ya masculina ya femenina, se decía "o logos" con artículo definido; sin embargo, cuando se hablaba de la razón común al hombre y la mujer, se escribía "logos”, sin artículo definido; es éste el uso que da Heráclito al decir: "Debemos escuchar al logos".

Pero logos significa también habla; Jenofonte en su obra Económico dice de su mujer que la llevó a la casa, donde: “...debia preguntar lo menos posible”. En Medea v.815), se lee: "...la mejor salvaguarda es que la mujer no discrepe de su marido”, y en Ayax: El silencio, es un adorno de las mujeres” (v.293). Penélope en la Odisea, por contraste con Ulises, calla y teje; su marido, idea, piensa, ingenia. No pareciera haber nacido sino para esto. La Guerra de Troya sin el ejercicio del logos-razón de Ulises, difícilmente se hubiese ganado. Telémaco, ya mayor de edad, se dirige con estas palabras a su madre: "Ahora, no estando mi padre en casa, yo soy el señor. Asi pues, dedicate a las tareas de tu sexo. Hila la lana, cuida las tareas de la casa, encárgate de la servidumbre, porque la palabra (mûthos, logos) es asunto de hombres". (Canto I - 1356). Añádanse las palabras de Hipólito: "A las mujeres se les debiera poner un bozal, como a las bestias, para que no hablen ni repliquen" (Hipólito: vv.645-648). ¡Excesivo! 
Esta actitud restrictiva con respecto a la palabra en boca de mujer - en ocasiones exagerada o mal interpretada - debe entenderse en el marco del respeto griego por la palabra y su uso. Escuchamos a Odiseo en Filoctetes (vv. 97-99): “ $Y$ ahora remitiéndome a las pruebas, veo que entre los mortales son las palabras y no los actos los que guian todo". La actitud de silencio y razón argumentativa referida la mujer, se ha de entender confrontándolo con aquel otro espacio - el ágora- en el que solo los hombres tomaban la palabra. Leemos en la Política de Aristóteles (Mex. Ed. Porrúa. 1975): "El esclavo no tiene en absoluto la facultad deliberativa; la hembra la tiene, pero ineficaz; y el niño la tiene, pero imperfecta. De aqui que quien mande debe poseer en grado de perfección la virtud intelectual... y cada uno de los demás en el grado que le corresponde".

¿Qué era esa "facultad deliberativa" que tiene la mujer, pero imperfecta? Para ello es necesario distinguir entre el logos-ágora de que habla Aristóteles y el logos-oikia; que la palabra del ágora fuese para el hombre, no quiere decir que la mujer fuese una silente; existía un logos-oikía propio de la mujer, el logos de la administración del hogar, que en pequeñas polis -como en nuestras aldeas de hoy- en realidad constituyen la totalidad social. Este logos femenino se extendía a otras muchas actividades sociales. Copio de Marina Picazo: "Aunque las fuentes escritas intentaran trasmitir la imagen de una extrema rigidez en la separación espacial entre mujeres y hombre y aunque el ideal social fuese que las mujeres no abandonasen la casa, su participación en las actividades sociales, económicas y religiosas exigian que lo hicieran; la contradicción se negociaba de diversas formas y seguramente mediante una compleja serie de normas y prohibiciones que permitiesen el fundamento de la ideología y la realidad viva" (p.88).

El logos persuasivo o logos-pathos perteneciente a la mujer, del que acabamos de hablar, tenía en la Grecia antigua su mejor expresión en la tragedia. Los nombres de las tragedias, en su mayoría son femeninos: Antígona, Medea, Fedra, Andrómaca, Hécuba, Electra, Euménides, Bacantes etc. etc. Es allí donde el logospersuasivo, - que es voz y no palabra, siguiendo a Aristóteles- tiene su especial presencia a través de la mujer; lo expresa en forma manifiesta Andrómaca al decir: "Pues, para las mujeres, por naturaleza, es un consuelo de los males presentes tenerlos sin cesar por la boca y en la lengua" (Andrómaca: v.93-94). La palabra "por naturaleza" no significa aquí constitución ontológica o modo esencial de ser, $\epsilon \mu \pi \epsilon \varphi \cup \varkappa \epsilon^{\prime \prime}$ es tener por dentro, implantado, término más débil, si bien, esta implantación deriva del verbo $\varphi \omega \omega$ semánticamente vinculado a naturaleza; en 
el mismo sentido hay que entender las palabras de Medea: "Somos por naturaleza incapaces de hacer el bien" (v.408). Kitto apoya ésta desde otra perspectiva filológica: Eurípides no tiene pensamiento formado en sus tragedias, se ha derrochado mucha tinta sobre esto, sus tragedias son efectistas, no ideológicas. Esto explica las llamadas "contradicciones" de los personajes de Eurípides, algo que ratifica Orestes (Electra, Eurípides): "Es que la naturaleza humana está en confusión”. Menelao pregunta a Orestes qué enfermedad padece, y éste responde "del entendimiento". Eurípides es el primer autor del teatro del absurdo. Algo que ya vio Dodds.

Medea dirá con respecto al logos-persuasivo: "Somos propensas a las lágrimas" (v.931), lágrimas "liberadoras" (v.1362). Lacan comenta al respecto, la mujer es "un cierto extravio"; ańadiré yo, "extravio con sentido o logos". Se lee en Medea, verso 38: "Su alma es violenta y no soportará el ultraje"; la palabra que usa Eurípides es phren (mente) ella no hace uso de la razón, se refiere aquí a la "razón-lógica" no al logos efectista euripidiano. Más adelante, " te phusin phrenós authadous", nuevamente el sustantivo ( $\varphi \rho \eta v$ "phren" en genitivo, "desmedida" o falta de razón, no de sentido, que diría Aristóteles. En el verso 45 se añade: "...pues ella es de temer", aquí la palabra usada es "deine", femenino de "deinos" y que Heidegger en la traducción de Antígona interpreta como asombro o lo no comprensible por vía de razón. Ahora entenderemos mejor aquello de la misma Antígona: "Asi que deja que yo y la locura, que es solo mía, corramos este peligro. No sufriré algo tan grave que no me permita morir con honor" (v.95-96); "locura" y "honor" -términos contradictorios- han de entenderse en ese "extravio con sentido", del que hemos hablado.

Si en la tragedia griega con frecuencia se habla de desmesura de la mujer, locura o falta de sentido, no es porque ello sea privativo de ella, la "bybris" que no es asunto patológico- está también presente en el hombre; más bien, si creemos a Teseo, existe en cada género, graduada: "La locura se encuentra en los hombres y crece en las mujeres" (Hipólito, v.967).

Pero existe también un logos-razonado que la mujer comparte con el hombre es ese logos usado sin artículo definido. Cuando en Fedra (v.376-377) se dice: "...he meditado como se destruye la vida de los hombres" y habla después de "la disposición natural de su mente", se está refiriendo con el genérico "hombres" a hombres y mujeres, que comparten la misma racionalidad ( $\gamma \nu \omega \mu \eta \zeta$ $\varphi \nu \sigma \imath \vec{\nu}$. Esta común razón es sujeto de derecho y deberes, y también de extravíos, pues está 
dada por la naturaleza o "fisis" (v.377) y se manifiesta de modo particular en la mujer, cuando es oprimida: "Cuando la mujer ve lesionados los derechos de su lecho, no hay otra mente más asesina"(258), leemos en Medea.

En virtud de este logos-natural el hombre y la mujer pueden llegar a las mismas alturas de excelencia: El Coro eleva a Alcestis a la misma gloria de los héroes homéricos, cuando se refiere a ella con el término heroico $\alpha \rho \iota \sigma \tau \eta^{\prime}$ v.150), palabra que repite Cerápena (v.151); más aún, en la antistrofa (v.1003), se la eleva a la gloria de las divinidades: "He aqui la que una vez murió por su esposo, y hoy es divinidad bienhechora". Ya las Bacantes habían elevado a la mujer a una dimensión divina, si bien excluida de un mundo de civilización urbana, arrojándola al espacio agreste del Citerón; y en cuanto a las esclavas, nada se oponía a que sus palabras, si así convenía, fuesen calificadas como nobles; Deyanira expresa: "Hijo mío, de gente villana salen a veces sabios consejos. Aqui tienes esta mujer; esclava es, pero ha hablado como persona noble", (v.63) aunque aquí se usa la palabra $\epsilon \lambda \epsilon \cup \vartheta \epsilon \rho o \nu$, en vez de la homérica palabra $\alpha \rho \iota \sigma \tau \eta$ Uno de los ejemplos, tal vez más claros, de esta presencia de logos-razón en la mujer, es el que se nos da en Ifigenia en Táuride: En el discurso argumentativo de Clitemnestra contra Agamenón en defensa de la vida de Ifigenia, el Corifeo, expectante, termina diciendo: "Ningún mortal puede objetar sus palabras" (v.1209).

En este contexto, el logos del hombre, no puede ir más allá del logos natural de la mujer. Hay cosas culturales en la configuración de lo femenino, pero en lo femenino existe un núcleo que es natural, y en esto: "La razón o es respetuosa de la naturaleza o no es razón", decía Aristóteles. La naturaleza pide un respeto a ambas formas de expresión racional, persuasiva y discursiva. Jasón atentó contra el logos persuasivo y discursivo de Medea. Este fue su grave error.

En el caso de Medea, observamos que oscila entre la ilógica hybris cultural y el logos natural de los derechos inalienables, lo que confirma el verso 889: "Pero somos lo que somos; no diré una calamidad, sino sencillamente mujeres". Otros textos pueden venir en apoyo de ello, pero han de ser matizados con lo que proclama el Coro en El Cíclope: "Ojalá que no hubiese nacido mujer alguna... a no ser para mi" (v.187). Muy lejos de la postura existencialista: "No se nace mujer, se llega a serlo. El género es un constructo social, un disfraz, una inexistencia. Es necesario una desconstrucción del término"; esto es cierto, pero como en el caso de Galileo, condenado por su teoría heliocéntrica, debemos terminar diciendo. "Eppur se mouve", (sin embargo, se mueve), es decir: "No obstante, los seres humanos nacen mayoritariamente hombre y mujer, para amarse y fecundar la especie, lo que constituye 
una ley natural, al ser ésta una verdad sostenida siempre, por todos y en todas partes", algo que Antígona afirma en estas palabras: "Estas no son leyes de hoy ni de ayer, sino de siempre, y nadie sabe de dónde surgieron" (v.457). ¿Qué es de aquellos que no pueden, no quieren fecundar o como dice El Cíclope: "Hasta cierto punto me gustan más los jóvenes que las mujeres" (v.584)? La ley natural, como toda ley, contempla también las excepciones, que no es de este lugar resolver.

Existía también un logos-rethoriké o de la demagogia, también censurado en los trágicos. Ha sido estudiado por Rodríguez Adrados en Fiesta, Comedia y Tragedia, por lo que no nos vamos a referir a ello. Recordemos solo la disputa Creonte-Hemón en Antígona y la alusión a los demagogos que en Hipólito hace el protagonista: "... los mediocres a juicio de los entendidos ante la multitud son más hábiles en sus discursos $\lambda \in \gamma \in \iota$ ’”"

En conclusión. ¿Era la mujer en Grecia una eterna silente? Pareciera que no.

\section{Polis}

Grecia era un mundo de ciudades, y tenían representantes que participaban en ellas; éstos eran, por razones militares, los hombres. "Los hombres, eran afectos a Ares", expresa Electra (Electra de Sófocles, v.938). Cómo no recordar que los niños - en vistas a la guerra- recibían una alimentación superior a la de las niñas (Jenofonte Constitución de los lacónios, 1. 3). Estaban excluidos de la participación ciudadana los menores de edad, esclavos, siervos y extranjeros; pero las mujeres participaban en forma indirecta; ellas eran el núcleo de la familia, y la democracia se entendía como una comunidad de familias. Dar hijos y cuidarlos, era tan importante como participar en forma directa en el ágora. Por otra parte, en un mundo de economía agrario-artesal, las actividades del hombre y la mujer, desde el punto de vista de la economía, eran igualmente valoradas: Administraba la primera el varón y la segunda la mujer. Jenofonte se encarga en el Económico de destacar la importa de la vida hacendosa de la mujer: Iscómaco compara a su mujer con la abeja reina, pues la mujer organiza el trabajo de los sirvientes, supervisa la casa, se preocupa del almacenamiento, administra los bienes, cuida a los enfermos, se preocupa del mobiliario, cocina, lava, educa a los hijos, muele el trigo, hace el pan, hila, teje, cuida a los niños pequeños, lleva el agua a la casa, prepara a la novia para su casamiento, ejecuta música, y le queda tiempo para participar en las actividades religiosas; la iconografía abunda en todas estas representaciones nada desdeñosas. 
La polis, como observamos, era la comunidad mayor en Grecia. La mujer era un elemento más de esa estructura mayor social. Entender su función en esta comunidad, es entender mejor la idea de mujer en Grecia. Hoy nuestra mentalidad está demasiado contaminada de un positivismo fragmentador, contrario al sentido holístico con que el griego veía el mundo. Hablar de la mujer en Grecia, como un elemento aislado del resto de la estructura social griega, es no entender el concepto de mujer. Es cierto que la cosmovisión griega estaba sustentada en un dualismo, elemento ordenador y de comprensión del mundo, pero que en la praxis no era excluyente: Griego-bárbaro; mundo de las ideasmundo de la realidad; Parménides-Heráclito; atenienses-espartanos; hombres libres-esclavos; Academia-Liceo; luz-tinieblas; mundo-inframundo; caballos blancos-caballos negros; convencer- persuadir; ágora-Partenón; sofrosine-ubrys; hombre-mujer... Detengámonos en esta última oposición: Se suele decir, en menoscabo de la condición de la mujer y valoración privilegiada del varón, que ella allí casi no tenía ni nombre, pues era conocida por sus funciones familiares, de esposa, madre, hermana etc. En realidad se trataba de potenciar el genos y desde éste la integración a la unidad social mayor que era la polis; el siglo $\mathrm{V}$ a.C. en Grecia es una larga etapa en la que, a diferencia de la arcaica (siglos VIII-VI a.C), buscaba fortalecer la estructura mayor de la polis, aún débil. Las heterías, grupos aristocráticos casi parapolíticos y el individualismo propio del griego, era una amenaza permanente a aquella deseada unidad democrática de la polis.

Los trágicos refuerzan este centro vital, que era la ciudad, desde muchos puntos de vista - las tragedias en su mayoría son tragedias de polis - pero de modo particular desde la ańoranza de la polis y el lamento por esta polis de la mujer. La polis tan incorporada a su vida cívica tenía a la mujer, que Electra dirá a Orestes con gran lamento: "Vivo lejos de la ciudad, entregada en mortal matrimonio"(Sófocles. Electra v.246). El mismo concepto expresa Andrómaca, y se lo recuerda el coro: "Reconoce que estás en tierra extranjera" (Andrómaca: v.135). La propia Andrómaca antepone en su lamento la pérdida de su ciudad a la pérdida de su esposo: "Tengo, no solo una cosa, sino muchas por deplorar: La ciudad de mi padre, y a Héctor que ha muerto... ” (vv.95-96). Lo repite Hécuba: "Vieja, sin hijos, sin ciudad, sola" (v.811). A estos tres lamentos de Electra, Andrómaca y Hécuba, en los que la polis está implicada, hay que añadir el de todas las mujeres de Tebas -forman el Coro de Los Siete contra Tebas- inconsolables cuando esta ciudad es asolada por la guerra fratricida entre Polínice y Etéocles; son calificados sus gritos como salvajes y se les pide se retiren a sus respectivos hogares. Para entender 
en sus reales términos tales lamentos, debemos enmarcarlos en lo que hemos llamado logos persuasivo femenino cuyo centro, en este caso, es el amor a la polis. Si bien, aún con este afecto y vinculación de la mujer con la ciudad, no era ella quien daba el nombre a los hijos, sino el padre; siendo mal visto en la polis que una mujer, como Clitemnestra, diese nombre a sus hijos, tal como declara Electra (v.925). La restricción participativa de la mujer en la polis lo expresaba también Edipo al contrastar y censurar la vida de las mujeres egipcias, en actividades fuera de la casa y ajenas a lo religioso (Edipo en Colono, vv. 337-345).

No sucedía así en Atenas. Una de las primeras responsabilidades de la mujer, y también del hombre era que las leyes del hogar y de los dioses se cumpliesen en la polis; esto es lo que justifica la acción valiente de Antígona ante Creonte defendiendo su derecho ciudadano: Enterrar a Polínice, pues la polis no está por sobre los divinos. Cuando, como en el caso de Las Bacantes, lo divino se impone a través de mujeres divinizadas, la polis, representada por Penteo, las rechaza. No sucedía en las fiestas religiosas oficiales. Debemos entender que la fiesta religiosa jugaba en Grecia un papel tan importante como el ágora. La estructura espacial de la polis obedecía precisamente a dos centros de atención: Arriba el Partenón, abajo el ágora. El incluyente se encontraba en lo alto, en el templo de Atenea. Era aquella una cultura de sacralidad y en ésta, la mujer, como se lee en la obra Manalipa cautiva de Eurípides, jugaba el papel principal : Pensad en lo que en mi opinión es lo más importante, su papel en la religión: Profetizan la voluntad de Loxias... revelan la voluntad de Zeus... los santuarios sagrados prosperan en manos de mujeres, lo que no sucedería en manos de hombres...tenemos una participación correcta en el servicio de los dioses".(Augustus Nauck (1964), frag.499, lin. 5-17). Incluso ante lo religioso, el hombre era inferior a la mujer: Ayax suplica a su esposa que entre y suplique a los dioses por él: "Tú, mujer, entra y suplica a los dioses que se cumplan enteramente los deseos de mi corazón” (v.685). Aristófanes en Lisistrata presenta un coro de ancianas que se declaran ciudadanas en virtud de su participación en los rituales religiosos. Los festivales de Deméter, eminentemente femeninos, tenían a su vez este mismo sentido de socialización democrática, pues la mujer establecía contactos con multitud de otras mujeres.

Existía a su vez, una relación muy cercana entre mujer, familia y polis en lo que a las costumbres se refiere, y que la tragedia no deja de lado, es lo que expresa Antígona a su padre Edipo: "Padre, es preciso que practiquemos las mismas costumbres que los ciudadanos, cediendo en lo que sea preciso y obedeciendo" (Edipo 
en Colono, vv.170-173). Entre estas costumbres se encontraba cuidar de los ancianos, según en viejo precepto délfico: "Los hijos que no cuiden de sus padres ancianos, que la polis se lo demande". Lo cumple Antígona, aun con riesgo de "no casarse o poder ser raptada" (v.745), dos aspectos muy valorados por la mujer griega. El mismo sentido de apoyo a la ancianidad se puede leer en Ayax (v. 510). En virtud de este apoyo a su padre, y no en otro sentido, como a veces se ha interpretado, Edipo dice de sus hijas: "Ellas son hombres, no mujeres"(v.1365).

Honra femenina y polis también es tema recurrente en la tragedia griega. La opinión deshonrosa de la polis hacia la mujer, deshonraba a la mujer; lo sabe Clitemnestra, que camina casi escondida, pues comprende "que la ciudad la odia", así dice Orestes al Anciano en los versos 637-639. La opinión, el "se dice" en Grecia, - así se ha dado en todas las sociedades- es un factor de decisiones. En Grecia, la mujer era la gestora de este poder oculto, pero tan decisivo que hace que una reina, como en el caso de Clitemnestra, camine con discreción; censura social, así mismo, era la hermosura de alguna mujer cuando, a causa de ella, alguien investido de autoridad podía en riesgo la ciudad, es lo que denuncia Deyanira (Las Traquinias v.467) y no es ajeno a ello el caso de Helena.

¿La no participación de la mujer en el ágora era realmente un menoscabo para la conciencia de la mujer griega? Desde el punto de vista de nuestra democracia, sí; desde el punto de la conciencia de la mujer griega, no; incluso, un ciudadano como Hipólito se siente feliz de no participar en tales debates, tantas veces enojosos, y aspira a vivir en la polis: "Ser siempre feliz en la ciudad en compañía de amigos excelentes, pues, en tales circunstancias es posible actuar y la ausencia de peligro proporciona mayor goce que el poder" (Hipólito:v.1020). Pertenece al espejismo griego creer que la polis era el espacio único del hombre y el oikos el espacio único de la mujer, y ello visto en una mentalidad de oposiciones. A partir del discurso de Demóstenes Contra Midias $(21,32)$ se puede colegir que existían tres espacios distintivos en Atenas: El del hogar, el de la ciudad sin representación pública - muy cercano al del hogar- y el de la ciudad actuando en nombre de la ley. A los dos primeros es a los que se refiere Hipólito como preferidos, muy frecuentemente deseados por los dos géneros.

\section{El Genos}

En este ámbito, preciso es distinguir tres conceptos: Anklisteia, oikia y genos; el orden de la significación es de mayor a menor: Anklisteia es el grupo 
familiar que incluye incluso a los esclavos, oikía supone consanguineidad, y genos consanguineidad en primer grado. La polis se constituye desde el oikos que en último término, no es sino la expresión última del genos. Las leyes, por su parte protegían estos fundamentos familiares de la ciudad. ¿Cómo se expresa esto en las tragedias griega?

Alcestis solicita imperiosamente que sus hijos perpetúen el genos tras su muerte (Alcestis, v.160), pues "los matrimonios como éste, benefician a los mortales", a la polis. (v.628). El lamento, con que tantas veces se insiste en la soltería obligada -caso de Antígona en Edipo en Colono, vv.745-752) - ha de entenderse en el mismo sentido, va más allá de nuestros sentimientos actuales sobre la "solterana", para la mujer griega era sentirse desvinculada de la cooperación en la perpetuidad de su genos. Ayax es una tragedia más incisiva, destaca tan fuertemente el genos que el daño de su protagonista es daño a su estirpe y alcanza a toda la ciudad: "Porque tú aniquilaste mi patria con tu espada" (v, 515). Nos estamos refiriendo, como en los casos anteriores, a Atenas, pues Esparta tenía otro tratamiento con la mujer y otra concepción sobre la polis y el genos; allí la lealtad a la ciudad, era antes que a la familia.

Dentro del genos tenía una especial preferencia el trato al padre. Tecmesa, en su esclavitud, recuerda a Ayax: "Yo naci de un padre libre, rico y poderoso cual ninguno entre los frigios" (485-490). Tecmesa acentúa, como lo hace Electra y Orestes, la presencia del padre; es que, dentro de la estructura del genos, existía la siguiente jerarquización: Primero el padre, después la madre y finalmente los hijos, los hermanos etc. Electra señala: "La mujer ama a su hombre, antes que a sus hijos" (Sófocles. Electra vv.264-265), algo que nos ayudará a entender la actitud de Medea frente a sus hijos y no su venganza directa contra Jasón, pudiendo como hechicera, hacerlo. El Corifeo en Antígona declara el origen paterno de la fiereza de la protagonista:" Se muestra la voluntad fiera de la muchacha que tiene su origen en un fiero padre. No sabe ceder ante las desgracias" (v.470). Vinculación directa con esto, lo tiene el duelo; para nosotros el duelo es temporal, significado por el luto; para el griego es duelo permanente, se trata de una carencia irreparable, "tiempo ha que fue asesinado Agamenón”, dice el Coro refiriéndose a Electra, permanencia que no censura al decir: "llorándolo toda la vida" (v.959), antes bien, el Coro "compadece" con ella. Duelo permanente, que entregará gloria interminable será el resultado, confiesa Antígona de la sepultación de su hermano: “¿Dónde hubiera podido obtener yo más gloriosa fama" (v.500-505); 
es ésta otra de sus motivaciones para enfrentar a Creonte: La primera, porque enterrar a los muertos es ley de los dioses; la segunda, que le viene de la fiereza de su padre; la tercera, para adquirir honra, fama, concepto tan importante en Grecia antigua; decía Alcibíades en el discurso a los atenienses acosejándoles la expedición a Sicilia:"... en mi opinión, los pensamientos del que procura por estos medios a su costa hacer honra y provecho, no solamente a si mismo, sino también a su patria, no deben ser tenidos por dañosos y perjudiciales a la república" (Tucídides. Historia del Peloponeso. L.VI). Más adelante, Aristóteles hará restricciones a este concepto de fama de Alcibíades y los trágicos: "La felicidad - dice en su Etica Nicomaquea-podría consistir en la fama o la gloria, porque por ella los hombres alcanzan en cierto modo la eternidad. Pero la fama o la gloria puede ser falsa. La fama o la gloria, depende de los admiradores, por lo cual no tiene consistencia propia, luego la felicidad no puede consistir en la fama o la gloria".

Las Troyanas nos abre otro ángulo enriquecedor del genos: El tema de la esclavitud. La esclavitud obligada, como es este caso, se valora negativamente al concebirse como un desprendimiento del tronco prestigioso familiar, " $y$ su linaje será motivo de oprobio" (v.505); dígase lo mismo de aquella queja de Electra, al ser obligada a estar casada con un "ajeno", un matrimonio que se califica como "oprobioso" (Electra, v.246). Finalmente en Ayax se apela al hijo sin padre, "privado de los cuidados que necesita la niñez" (v.510-515). En Grecia el hijo huérfano cargaba con doble deficiencia: Sin la protección del padre y desprendido del espíritu del genos paternal. La situación menoscaba de Orestes y Electra, en Electra de Sófocles, supone esta doble carencia, que les llevará a tramar la muerte de su madre Clitemnestra. El recuerdo del padre como un "entrañamiento genético", más que como un sentimiento, se encuentra también en Antígona cuando expresa: “;Oh padre! ;Oh querido! ¡Oh tú, envuelto en la eterna oscuridad bajo tierra, ni aunque te hayas ido te encontrarás sin mi cariño y el de ésta!" (vv. 1700-1703); la idea se repite en Alcestis por boca de Admeto: "Muerta, serás también mi única espos" (v.329).

\section{Conclusión}

Es muy difícil liberar a la mujer griega de su consideración social secundaria. Sin embargo, cuando el concepto de misoginia se aquilata, como hemos pretendido en este estudio, observamos que emerge para ella una dignidad que a veces nos sorprende. Ella era portadora de un logos que Homero (Ill., XIV, 153-189), la retórica, la poética y las tragedias griegas destacan y ponen a la 
altura del logos dialéctico masculino. El término callar y acallar al otro género, referido a la mujer, creo que no es posible seguir sosteniendo; remito en esto al interesante estudio de Héctor García sobre los engaños de Hera a Zeus (Bizantón Nea Hellás, $\mathrm{N}^{\circ} 31,2012$ ), pocas veces, tal vez ninguna en la historia de la literatura, la mujer -en esta caso Hera- ha callado más, con un lenguaje de seducción más elocuente. La polis, por otra parte, era-como hemos demostradoun oikos ampliado, y en el oikos -si creemos a Jenofontes- ella, la mujer era la reina ordenadora. Con respecto al genos, y la tan traída como llevada frase que leemos en las Euménides, "la mujer no es la madre, presta solo el vientre", una visión holística como la que hemos estudiado, nos dice que dichos como éste no dejan de ser más que una frase taxativa, a la que con tanta frecuencia estaba propenso el decir griego, amante de las definiciones. El decir sentencioso en Grecia no tenía siempre el valor de conclusión de un silogismo y, en muchas ocasiones, era mera expresión de una opinión personal: Los Dichos de los Siete Sabios de Grecia, los Consejos de Sócrates, el agudo Dicterio de Diógenes, la discreción de los Principios de Pitágoras, los Axiomas de Euclides, los Fragmentos de Heráclito, los veinte Consejos y Recomendaciones de Hipócrates, todo un decir sentenciosos que condensa Diógenes Laercio (siglo III a.C) en Vida, opiniones y sentencias de los filósofos griegos, es una muestra más del cuidado que debemos tener con las afirmaciones griegas, no siempre definitorias, y tan presentes en la tragedia griega, particularmente en Eurípides. 


\section{Referencias bibliográficas}

Antígona. (2000), Madrid. Edit. Gredos.

Alcestis (1994). Ed. D. Kovacs. Loeb Classical Library - Harvard University Press, Cambridge.

Ayax.(2000). Madrid. Edit. Gredos.

Alcestis y Bacantes. (2006). Madrid. Edit. Gredos, Trad. Y notas de J. L. Calvo, C. García Gual y L. A. de la Cuenca, revisión de A. Bernabé.

Alvarez, Nariza (2004). "Medea, la mujer transgresora". Costa Rica. Revista de Artes y Letras. Vol. XVIII.

Aristóteles. (1975). Política, 1, 13,7-8. Buenos Aires. Ed. Porrúa.

Aristóteles (1990). Retórica. Madrid. Ed. Gredos.

Cyclops1994). Ed. D. Kovacs. Loeb Classical Library - Harvard University Press, Cambridge.

Demóstenes. Discurso Contra Midias (21,32). DILTS, M. R. (2006), Demosthenis Orationes II, Oxford.

DodDs, E.R. (1994). Los griegos y lo irracional. Madrid. Alianza Editorial.

Diógenes Laercio (2007). Vida, opiniones y sentencias de filósofos antiguos. Madrid. Alianza Editorial.

Edipo en Colonon (1981). Madrid. Edit. Gredos, trad. De Assela Alamillo.

Electra -El Cíclope (1962) Madrid. Col, Los Clásicos, EDAF (traduce José Alemany Bolufer y Federico Baráibar y Zumárraga.

Esteban Santos, Alicia (2007). De princesas a esclavas. En Troya (Heroinas de la mitología griega III". Madrid. Universidad Complutense de Madrid. Dpto. de Filología Griega y Lingüística Indoeuropea.

Filoctetes. (1981). Madrid. Edit. Gredos. Introd. De José Lasso S. de la Vega. Trad. Assela Alamillo.

García C. Héctor (2000-2001) "Perfil de Antígona en la Antígona de Sófocles", en Byzantion Nea Hellas, 19-20. Anuario del Centro de Estudios Griegos, Bizantinos y Neohelénicos de la Universidad de Chile.

García C. Héctor (2012). "Homero en vivo entonces y ahora" (conferencia leída en la Universidad de Cuyo, reproducida en Bizantion Nea Hellas, $\mathrm{N}^{\circ} 31$, 2012. Centro de Estudios Griegos y Bizantinos de la Universidad de Chile. 
García Álvarez.C. (2014), "La idea de justicia en la tragedia griega”. Revista de la Facultad de Derecho de la Universidad María Cristina, "La Ciudad de Dios". Madrid (El Escorial).

García Álvarez, C. (2001). Lecciones sobre la tragedia griega. Santiago de Chile. Centro de Estudios Griegos y Bizantinos de la Universidad de Chile.

Hipólito. (1998). México. Edición de la UNAM: Bibliotheca Scriptorum Graecorum et Romanorum Mexicana, trad. Rubén Bonifaz Nuño.

Hamamé, Graciela Noemí (2000). Yocasta. Un itinerario trágico en Fenicias de Euripides. La Plata, Argentina, en Revista "Sinthesis". N 7. Ed. Bibhuma.

Iriarte, Ana. (1996). Ser madre en la cuna de la democracia o el valor de la paternidad. Madrid, Ed. Cátedra.

Loraux, Nicole (2004) Madres en Duelo. Madrid. Edit. Abada, S.I.

Medea (2000) Madrid. Edit. Gredos. Trad. Alberto Medina González y Juan Antonio López Pérez.

Medea. (1994). Ed. D. Kovacs. Loeb Classical Library - Harvard University Press, Cambridge.

Mosse, Claude.(1990). La Mujer en la Grecia Clásica. San Sebastián. Edit. Nerea.

Müller de Inda, Cilly (1996). "Conciencia de la responsabilidad: Alcestis y Antígona". Universidad de la Plata. Revista Memoria Académica vol. 3, pp. 19-31.

Perrot, Michelle (2009). Mi historia de las mujeres. Buenos Aires. Edit. F.C.E.

Picazo Gurina, Marina.(2008). Alguien se acordará de nosotras. Mujeres en la ciudad griega antigua. Barcelona. Edit. Bellaterra.

Sarah B. Pomeroy (1990). Diosas, Rameras, Esposas y Esclavas. Madrid. Edit. Akal.

Sófocles (1804) The Electra of Sofhocles, Ed. Richard Jebb. Cambridge. University ress, Cambridge. Hemos tomado en cuenta las ediciones de Gredos, traducción y notas, José Luis Calvo Martínez.

The Trachiniae (Obras en Perseus Digital Library). 